\title{
Lutas sociais e desafios da classe trabalhadora: reafirmar o projeto profissional do serviço social brasileiro
}

\author{
Social struggles and challenges the working class experiences: \\ reasserting the Brazilian social service professional project
}

\author{
Maria Beatriz Costa Abramides \\ Doutora em Serviço Social, professora do Programa de Pós-Graduação em Serviço Social da PUC-SP, \\ coordenadora do Núcleo de Estudos e Pesquisas em Aprofundamento Marxista-Neam, São Paulo/SP, Brasil. \\ biabramides@gmail.com
}

Resumo: O trabalho pretende analisar os desafios postos à classe trabalhadora frente à conjuntura do país, no período que vai de 2013 ao primeiro semestre de 2016, com a grave crise política decorrente da crise econômica do capitalismo e seus ataques aos direitos sociais e trabalhistas. Retoma os antecedentes dessas crises, o caráter defensivo das lutas, mobilizações e greves a partir de 2013, bem como a necessidade da construção de uma frente única classista anticapitalista. Estabelece a relação entre projeto profissional e projeto societário classista na perspectiva emancipatória.

Palavras-chave: Classe trabalhadora. Lutas sociais. Projeto profissional. Projeto societário.

\begin{abstract}
The article aims at analyzing the challenges the working class is experiencing due to the country's situation from 2013 to the first term of 2016, with the serious political crisis, owing to the economic crisis of capitalism and its attacks on the social and labor rights. It resumes the background of such crises, the defensive character of the struggles, mobilizations and strikes, from 2013 on, and the necessity to build a single anticapitalist class-ridden front. It establishes the relation between the professional project and the class-ridden society project from the emancipatory perspective.
\end{abstract}

Keywords: Working class. Social struggles. Professional project and class-ridden project.

\section{I - INTRODUÇÃO}

$\mathrm{O}$ presente artigo pretende resgatar os desafios e respostas da classe trabalhadora por meio das lutas sociais no Brasil, a partir de 2013, período de mobilizações explosivas de massas, até as lutas vividas no primeiro semestre de 2016, frente à ofensiva do capital pelo aprofundamen- 
to de sua crise estrutural. A análise recorre às determinações sócio-históricas do ponto de vista dos interesses do capital e do trabalho, no processo de organização da classe trabalhadora na luta pela manutenção de seus direitos sociais e trabalhistas, pelo fim da propriedade privada dos meios de produção, do trabalho alienado, do sistema capitalista e na conquista de uma sociedade emancipada, igualitária e libertária, comum a todos, a que Marx denominou comunista. $\mathrm{O}$ trabalho busca estabelecer a relação e o compromisso dos profissionais nos marcos de ruptura com o conservadorismo conquistado pela categoria dos assistentes sociais na direção dos interesses imediatos e históricos da classe trabalhadora ao longo dos últimos 37 anos, face aos desafios postos na contemporaneidade.

Desde 2013 a conjuntura do país apresenta um quadro de grandes mobilizações sociais frente aos ataques do capital, por meio do patronato e do Estado, com precarização das condições de vida dos trabalhadores imposta pela terceirização, desemprego estrutural crescente, desregulamentação das relações de trabalho e cortes orçamentários em políticas sociais que reduzem direitos sociais e trabalhistas arduamente conquistados. Assistimos à criminalização dos movimentos sociais nos vários estados, com repressão contínua aos lutadores, fortalecida com a aprovação da lei antiterror, sancionada em 2016 pela presidente Dilma Rousseff, um poderoso instrumento de criminalização dos movimentos sociais e ampliada no governo golpista de direita em curso no país sob a presidência ilegítima de Michel Temer, do Partido do Movimento Democrático Brasileiro (PMDB). As lutas de resistência da classe trabalhadora e da juventude com greves, mobilizações de rua, ocupação de terras, fábricas e escolas têm sido intensa no processo contra a exploração econômica, dominação política e opressão social de classe, gênero, raça, etnia, geracional e de orientação sexual. Tais reivindicações se relacionam diretamente à direção social do projeto profissional do Serviço Social brasileiro articulado ao projeto societário emancipatório. De outro lado, nos é muito caro o processo de autonomia e independência das entidades organizativas da classe trabalhadora em relação ao Estado, ao governo e ao patronato e na particularidade das entidades de representação da categoria profissional que conquistamos e consolidamos hegemonicamente. 


\section{II - DESENVOLVIMENTO}

\section{A crise estrutural do capitalismo}

Analisar os conflitos e antagonismos de classe no Brasil pressupõe apresentar os elementos constitutivos da crise estrutural do capitalismo no plano internacional e a programática para a América Latina, cujas medidas recaem sobre os trabalhadores, a partir de 1989, com várias contrarreformas, cujos planos de austeridade são aprofundados mais intensamente a partir da crise de 2011. Para compreendê-los, apresentamos os vetores dessa crise, em meados dos anos 1970, no plano internacional do capitalismo, e sua posterior expansão, que incidem na destruição de direitos sociais e trabalhistas e na ampliação da precarização da vida dos trabalhadores. O capital possui leis gerais, e suas crises cíclicas são inerentes à sua lógica sistêmica e orgânica destrutiva. A partir de 1973, o capitalismo vive uma crise estrutural no plano internacional, advinda da queda tendencial da taxa de lucro e da crise de superprodução, que o condiciona a estabelecer novas estratégias para retomar e ampliar seu processo de acumulação. Essa ofensiva se estabelece na esfera econômica, na produção social do mundo do trabalho, na esfera política, no Estado e na dimensão da cultura.

A ofensiva do capital, para superar sua própria crise, se direciona a uma nova forma de gestão das relações de trabalho, pela "acumulação flexível desenvolvida no processo de reestruturação produtiva para retomar as taxas de lucro para o capital, ampliando a exploração da força de trabalho humana. Desregulamenta as relações trabalhistas com desemprego estrutural, precarização do trabalho, ampliação do trabalho informal, redução do operariado fabril contratado, subproletarização e substituição de trabalhadores contratados por terceirizados, que se expandem pelos serviços, contratados por tempo determinado, por projetos, por serviços sem carteira assinada, por pessoa jurídica e com alta rotatividade no trabalho imposta pelos empregadores que reduzem violentamente os direitos dos trabalhadores. O estado de dominação, a serviço do capital, implanta a programática neoliberal com contrarreformas do Estado, sindical, trabalhista, da Previdência Social e educacional, cujos ajustes fiscais implicam diretamente cortes na saúde, na educação, na habitação, no sistema 
previdenciário, na reforma agrária e na precária demarcação das terras indígenas e quilombolas, uma dívida histórica com as populações originárias. A privatização das estatais e a mercantilização se constituem em metas nas quais o fundo público se desloca para a iniciativa privada em detrimento dos serviços públicos e das políticas universais. Na esfera da cultura, a ofensiva do capital se orienta pela "pós-modernidade" em sua tônica ideopolítica de negação das teorias estruturantes, de propagação do capitalismo triunfante em que prevalece o presentismo, o irracionalismo, o estímulo à competitividade e ao individualismo. A articulação dessas esferas atinge a objetividade e a subjetividade da classe trabalhadora no sentido de cooptá-la ao projeto de exploração e dominação de classe, destruindo a força de trabalho e acelerando o sofrimento psíquico das pessoas mediante a precarização da vida.

Na América Latina, a investida neoliberal ocorre a partir do Consenso de Washington, em 1989, como estratégia para o continente, no processo crescente da internacionalização da economia, no capitalismo dos monopólios, do imperialismo, em sua última etapa. A situação dos países dependentes e periféricos, sob a lógica do "desenvolvimento desigual e combinado", agrava substancialmente a precariedade das condições de vida e de trabalho. O traço comum, constitutivo da programática neoliberal, consiste em dar continuidade à submissão dos países latino-americanos ao grande capital internacional, de financeirização da economia, e continuidade do capital produtivo para ampliação da exploração do trabalho na produção de valor e mais-valia, alterando substancialmente suas condições de existência de forma regressiva e demolidora no processo do capitalismo em sua fase atual.

\section{Ofensiva do capital na conjuntura brasileira: 2013-2016}

As primeiras medidas do neoliberalismo no Brasil se concretizaram no final do governo Sarney, em 1989, solapando as conquistas obtidas pelos trabalhadores na Constituição de 1988, recém-aprovada. A seguir, o neoliberalismo no governo Collor de Mello estabelece a liberalização comercial, o que estimula e acelera a livre concorrência do mercado internacional e destrói postos de trabalho por meio de demissões maciças de trabalhadores. O neoliberalismo prosseguiu 
no governo Itamar Franco e se aprofundou nos dois governos de Fernando Henrique Cardoso (FHC), com as contrarreformas do Estado, da Previdência Social, sindical, trabalhista, do ensino superior, e no avanço das privatizações das estatais rentáveis. Nos dois governos de Lula da Silva e no primeiro e segundo de Dilma Rousseff, o neoliberalismo teve sua continuidade, o que contraria a programática inicial do Partido dos Trabalhadores, construído a partir das lutas dos movimentos sociais classistas nos anos 1980. A Carta ao Povo Brasileiro, apresentada por Lula em 2002, já anunciava de que maneira o "governo democrático popular" se dirigiria à nação por meio de alianças com setores da classe dominante para implementar sua política, o que caracterizou o governo do PT como de conciliação de classes. Desde a formação do primeiro governo do PT, as alianças e bases de apoio com partidos burgueses foram estabelecidas, e as medidas de maior "austeridade", contra os trabalhadores, ocorreram no segundo mandato de Dilma Rousseff, a partir de 2015. Em que pesem os programas sociais implementados pelos governos do PT aos setores mais pauperizados, eles foram desvinculados de políticas estruturantes, o que se reproduz na lógica da desigualdade, além da redução de recursos financeiros para investimento em políticas sociais universais, como saúde e educação. Isso significa que o chamado neodesenvolvimentismo ou social-desenvolvimentismo implantado pelos governos do PT teve seus dias contados, mediante o esgotamento desse modelo pela própria ofensiva do capital.

Os desdobramentos da conjuntura do país no período do governo Dilma Rousseff, de 2013 a 2016, foram de ataques aos direitos sociais e trabalhistas pelos ajustes fiscais, cortes no orçamento dos programas sociais, decretos emitidos pela presidente, projetos aprovados pelo Congresso Nacional, ofensiva das empresas e do Estado de precarização do trabalho. Além disso, efetivou-se o golpe institucional parlamentar de direita, com a abertura de impeachment $\mathrm{e}$ afastamento por 180 dias de Dilma Rousseff. O presidente ilegítimo Michel Temer, do PMDB, aprofunda e acelera ainda mais a destruição dos direitos sociais e trabalhistas a serviço do grande capital. De outro lado, as lutas sociais de resistência dos trabalhadores e da juventude se espraiaram por vários estados e fizeram enfrentamento ao governo do PT por suas medidas antissociais, bem como aos conservadores e reacionários, sob a orientação do Partido Social Democrático Brasileiro (PSDB) e do PMDB nos estados e municípios. 
Vivemos um momento histórico de decomposição do capitalismo em que as forças produtivas encontram-se em antagonismo com as relações sociais de produção, e nesse período há uma possibilidade histórica de revolução social, desde que estejam colocadas as condições objetivas e subjetivas para a luta anticapitalista e socialista. A análise marxiana é a de que as condições objetivas estão dadas pelo atual estágio do capitalismo, face à destruição constante e progressiva de forças produtivas, porém as condições subjetivas dependem da organização dos partidos proletários e das lutas de oposição revolucionária ao capitalismo, e essa é uma tarefa histórica dos marxistas revolucionários no plano nacional e internacional.

\section{Organização sindical}

Os fundamentos, contradições e medidas destrutivas contra os trabalhadores serão apresentados nos aspectos que conformam o capitalismo na conjuntura do país pela correlação de forças com as massas trabalhadoras e desafios para a luta de classes. Analisar o período que vai de 2013 aos primeiros meses de 2016 pressupõe, do ponto de vista da classe, acompanhar a ação defensiva dos trabalhadores a partir de 1989, com a avalanche neoliberal no Brasil nos anos 1990, e sua evolução até os quinze primeiros anos do século XXI. Se os anos 1980 expressaram uma vigorosa e combativa luta sindical e popular classista, autônoma e independente, com a fundação da Central Única dos Trabalhadores (CUT) em 1983 e do Movimento dos Trabalhadores Sem Terra (MST) em 1984, a perspectiva sindical se altera nos anos posteriores, ocorrendo uma retração das lutas. Nos anos 1990, com as transformações do mundo do trabalho desencadeadas pelo processo de "acumulação flexível", o sindicalismo se encontrou atado à imediaticidade para a garantia de direitos que estavam sendo destroçados no mundo do trabalho e na esfera do Estado pelo processo de desregulamentação e precarização das relações trabalhistas.

De outro lado, a filiação da CUT à Central Sindical Internacional Social Democrata (Ciols) fez com que abdicasse da ação direta das grandes greves e atuasse nos marcos de negociações na institucionalidade, que abdicavam das manifestações de massa anteriormente desencadeadas. Nos dois governos de 
FHC o movimento sindical negociou, fundamentalmente, por intermédio das câmaras setoriais compostas pelo patronato, pelo governo e pelo sindicato em uma comissão tripartite desigual, acrescida do fato de que essa negociação prescindira da ação direta, de greves de fábrica, organização nos locais de trabalho que pudessem dar sustentação da classe às reivindicações. A direção política foi a da negociação de "concertação" característica do sindicalismo social-democrata de conciliação de classes. Soma-se a esse giro reformista um neocorporativismo, posto que os sindicatos de trabalhadores, outrora classistas, não incorporaram os trabalhadores terceirizados na base das categorias, negociando somente os interesses dos contratados. Um outro elemento, não menos importante, foi a ilusão disseminada nos anos 1990, de que a participação social via canais institucionais de participação popular incentivados nas prefeituras e estados governados pelo PT no denominado "modo petista de governar" seria o suficiente, em detrimento das ações extrainstitucionais, das ações diretas, das greves, e os sindicatos anteriormente se ativeram ao limite das negociações, confundindo-se com o sindicalismo de resultados da Força Sindical, acrescidas das ações de mais treze centrais sindicais pelegas, que não representam os interesses de classe.

O sindicalismo combativo, de base, organizado desde os locais de trabalho, de concepção e prática sindical classista e socialista, sempre defendeu o fim do atrelamento do sindicato ao Estado. É nesse sentido que a Central Sindical Popular (CSP), - Conlutas e a Intersindical se organizaram como centrais sindicais com autonomia e independência de classe, além de espaços como o da Unidade de Ação, mas ainda insuficientes no alcance de direção e unificação das lutas desencadeadas pelos movimentos massivos que se generalizaram a partir de 2013. Nesse sentido, é tarefa primeira do movimento social a necessidade de construir um bloco de esquerda autônomo, independente e classista de oposição revolucionária ao capital. Essa tentativa encontra-se ainda bastante embrionária, o que faz com que as ações não ganhem permanente unidade na luta, além de torná-las em grande parte atomizadas em suas lutas particulares, importantes, mas aquém das exigências postas aos trabalhadores no processo da luta de classes.

A partir de 2003, no primeiro governo Lula, a CUT se constituiu como base de sustentação dos governos do Partido dos Trabalhadores (PT) e não se 
deu de forma diferente com o MST, em sua posição hegemônica. Os dois movimentos de base proletária, operária e de trabalhadores sem terra mais expressivos, que imprimiram lutas e conquistas significativas anteriores, ao abdicarem da autonomia e independência de classe, se tornaram obstáculos para a luta autônoma dos trabalhadores. Portanto, outro desafio ao sindicalismo é o de que a CUT, a Central de Trabalhadoras e Trabalhadores do Brasil (CTTB) - braço sindical do Partido Comunista do Brasil (PCdoB) e o MST rompam com a subordinação ao governo Dilma Rousseff e aos governos em geral do PT, nos planos estaduais e municipais; retomem a autonomia e a independência de classe para virem a construir nesse campo as lutas sociais mais que necessárias contra o ajuste fiscal, os decretos e os 55 projetos de lei que estão em tramitação no Congresso Nacional contra os trabalhadores desde o governo Dilma e acelerados com o governo ilegítimo de Temer, que segue à risca e amplia os ditames do capital internacional de austeridade contra os trabalhadores e suas famílias, acelerando medidas, decretos e projetos de lei a ser votados.

\section{Conjuntura no país (2015-2016): golpe de Estado, ajuste fiscal, decretos e projetos em tramitação no Congresso Nacional}

\subsection{0 golpe institucional parlamentar}

A conjuntura atual no Brasil apresenta, desde 2015, um Congresso Nacional considerado o mais reacionário dos últimos cinquenta anos. As classes dominantes, há séculos no aparelho estatal, reacendem cotidianamente seu poder de dominação e opressão de classe sobre os trabalhadores. O golpe parlamentar de direita foi impulsionado pelo líder da Câmara, deputado Eduardo Cunha, do PMDB, que apesar dos inúmeros processos de corrupção, somente foi afastado do cargo em 5/5/2016, o que o permitiu presidir a sessão do dia 17/4/2016, de abertura de impeachment contra a presidente Dilma Rousseff. Esse instrumento de impedimento tem sido evocado quando um governo, embora siga as orientações macroeconômicas do grande capital, não interessa mais aos grupos hegemônicos de direita que estão no governo ou no parlamento e 
buscam medidas ainda mais duras da ortodoxia neoliberal em defesa do capitalismo e de sua hegemonia. O golpe institucional parlamentar, em curso desde dezembro de 2015, atende aos interesses da burguesia, do grande empresariado, da Fundação das Indústrias do Estado de São Paulo (Fiesp), da oposição de direita representada pelo PSDB, e PMDB (este coligado ao governo Dilma até as vésperas do golpe), de partidos menores de direita a eles aliados, dos grandes meios de comunicação, da Rede Globo e dos jornais e revistas de grande circulação, do agronegócio, da Polícia Federal, do Ministério Público, da Ordem dos Advogados do Brasil (OAB), do Movimento Brasil Livre (MBL), movimento de direita que, frente a um governo enfraquecido, articulou-se interna e externamente para manter-se no poder em defesa de seus interesses de classe a serviço do capital nacional e internacional, agora sob a direção da direita via "golpe institucional". O PSDB, não satisfeito por ter perdido a eleição presidencial, articula o impeachment a partir de uma manobra de Eduardo Cunha e Michel Temer, vice-presidente da República, ambos do PMDB, partido presente em todos os governos, inclusive no do PT, com seu oportunismo e fisiologismo. De outro lado, cabe lembrar que $70 \%$ dos parlamentares que aprovaram a admissibilidade do impedimento, sem crime de responsabilidade, estão comprometidos com a corrupção. Na tarde e noite de 17/4/2016, a farsa se concretizou por meio das intervenções dos(as) deputados(as) que exaltaram a propriedade privada, Deus, a família, os evangélicos, a maçonaria, em um obscurantismo absoluto; os parlamentares mais reacionários prestaram suas homenagens à ditadura militar e aos torturadores, além das críticas homofóbicas ao direito da livre orientação sexual, e em sua esmagadora maioria sequer apresentaram argumentos referentes à pauta do impedimento, de existência ou não de crime de responsabilidade. Presenciamos "um filme de horror" instaurado sob a exaltação do cretinismo parlamentar, como nos alertava Lênin sobre o papel do Legislativo. Votaram pelo impeachment 367 deputados de partidos de direita (PMDB, PSDB, PPS, DEM, PP, DEM, PSB, PTB, PV), além de partidos menores fisiologistas de direita, e da Rede de Marina Silva. É importante lembrar que grande parte desses partidos foi base de apoio e coligação do governo Dilma, até selar o compromisso com o golpe de Estado. Votaram contra o golpe 137 deputados(as) do PT, PCdoB, PSOL, PDT e PR (parte), além de um ou outro voto desgarrado de seus partidos, sete abstenções e duas ausências. O processo 
de admissibilidade foi aberto e seguiu para o Senado. Em 11/5/2016, por 55 votos favoráveis e 22 contrários, os senadores selaram o impeachment da presidente Dilma Rousseff, e em 12/5/2016 assumiu interinamente, por 180 dias, o vice-presidente Michel Temer, em um golpe contra a soberania nacional do voto de 54 milhões de brasileiros. Em 31/8/2016, momento em que concluo este artigo, o Senado aprovou por 61 votos a favor e vinte contra, o impeachment da presidente Dilma. Está consumado o golpe institucional de direita no país. A Lei de Responsabilidade Fiscal, imposta pelo neoliberalismo, golpeia a nação, e 61 oligarcas sequestram o voto popular. Nos posicionamos contra o golpe parlamentar e o governo ilegítimo de Temer do PMDB de "ponte para o abismo", que tem ampliado e continuará expandindo as medidas de ataques aos trabalhadores e à juventude, em uma ortodoxia de direita e neoliberal, conforme explicitado desde o primeiro dia da posse ilegítima e que vem se consolidando por meio de: privilegiamento do setor privado, privatização das estatais, contrarreformas trabalhista e previdenciária, com mais cortes no orçamento para a educação, saúde, habitação, com repressão aos movimentos sociais, como a medida de desocupação das escolas sem mandado de reintegração de posse e prisão de estudantes secundaristas, as medidas de contrarreformas serão aceleradas e os ataques aos trabalhadores serão brutais. De outro lado, é importante reafirmar que nos colocamos em oposição à política de conciliação de classes do governo petista com a burguesia em um projeto que seguiu à risca a lógica destrutiva do capital de forma mais dura a partir do segundo mandato da presidente Dilma Rousseff. O momento exige que a classe trabalhadora, no campo de sua autonomia e independência, se organize para a dura luta que está colocada contra o governo ilegítimo e suas medidas e na construção de uma greve geral no país.

\subsection{Projetos de lei em tramitação, decretos-lei e ajuste fiscal de ataque aos trabalhadores}

Em 2016, de acordo com o Departamento Intersindical de Assessoria Parlamentar (Diap), tramitam 55 projetos no Congresso Nacional de destruição dos direitos e conquistas dos trabalhadores. Desses, 25 encontram-se em andamento desde 2013, ou seja, quase 50\%. Outros são de períodos anteriores e foram retomados mais recentemente no governo Dilma e Temer. As ameaças 
desses projetos se referem a: regulamentação da terceirização para atividades-meio e ampliação para as atividades-fim; retirada do direito de greve do trabalhador no serviço público; alteração da CLT com a prevalência do "negociado sobre o legislado", que permite perdas como redução do $13^{\circ}$ salário, licença-maternidade e licença-paternidade; redução da jornada de trabalho com redução de salário; redução da idade de dezesseis para catorze anos para inserção em regime parcial no trabalho; inviabilizar o trabalhador demitido de reclamar direitos na Justiça do Trabalho; realização de trabalho intermitente por dia e hora com prestação de serviços descontínua; extinção da multa por demissão sem justa causa; regulamentação do conceito análogo ao trabalho escravo; instituição de contrato de trabalho de curta duração; ampliação da jornada aos trabalhadores rurais para doze horas, com a possibilidade de mais duas horas extras, que atualmente já contabilizam dez horas de trabalho; suspensão do contrato de trabalho; estabelecimento do Simples Trabalhista, ao criar outra categoria de trabalhador com menos direitos; o deslocamento do empregado até o local de trabalho e retorno à casa não será considerado jornada de trabalho, $\mathrm{e}$ se houver acidente no percurso ou morte, os trabalhadores estarão descobertos de direitos; extinção do abono-permanência. Outras medidas de avanço da privatização e de ataques aos direitos sociais, de gênero, raça, etnia e orientação sexual também estão previstos, como: restrição na demarcação das terras indígenas; alteração do Código Penal sobre a questão do aborto, criminalizando ainda mais as mulheres e profissionais da saúde; instituição do Estatuto da Família; retrocesso para grupos LGBTs, pelo não reconhecimento como família, ficando, portanto, fora do alcance das políticas do Estado; instituição do Estatuto do Nascituro, que ameaça os direitos reprodutivos da mulheres, inviabilizando inclusive o aborto previsto no Código Penal; aumento do tempo de internação de adolescentes no sistema socioeducativo; retirada do termo gênero do texto das políticas públicas; tramitação do PL n. 867/2015 do Programa Escola sem Partido, que pretende incluir na Lei de Diretrizes e Bases (LDB) da Educação a negação à liberdade de expressão dos professores com o intuito de aniquilar o conteúdo crítico nas salas de aula, e a educação como fonte de conhecimento das causas reais das mazelas do capitalismo com a exploração, desigualdade, opressão e dominação de classe; fim da exclusividade da Petrobras na exploração do pré-sal e estabelecimento do regime de concessão às empresas 
privadas na espoliação da riqueza nacional. Esse conjunto de medidas destrói conquistas sociais e trabalhistas e amplia a subordinação à perspectiva privatista e mercantil de assalto ao fundo público de desmonte da nação.

O mais nefasto dos projetos aprovado na Câmara dos Deputados e em tramitação no Senado se refere aos direitos trabalhistas, sendo que a ponta do iceberg de sua destruição é o PL n. 30/2016, que trata da terceirização para todas as atividades. O sindicalismo classista expresso na Conlutas e na Intersindical se contrapõe a todas as formas de terceirização, seja nas atividades-meio ou nas atividades-fim. A CUT e a CTTB são contrárias às terceirizações das atividades-fim, mas apoiam as medidas do governo Dilma, do Congresso Nacional e do presidente ilegítimo Temer de regulamentar as terceirizações das atividades-meio. Esse projeto pretende terceirizar todas as esferas da economia, os setores público e privado, o que colocará toda a classe trabalhadora no processo demolidor das relações de trabalho. Além dessas medidas, pode-se acrescentar outras desencadeadas pelo governo golpista de Temer com a extinção do Ministério de Direitos Humanos, das Mulheres e da Igualdade Racial, agregando-os ao Ministério da Justiça, o que afeta as mulheres, indígenas, afrodescendentes, pessoas LGBTT, comunidades originárias, sob a coordenação do ministro Alexandre Moraes - denominado "pitbull" até por um jornal conservador que é o Valor Econômico - , que foi secretário de Segurança do governo estadual de Geraldo Alckmin em São Paulo e ordenou, sem mandado de segurança, que a polícia militar invadisse violentamente as ocupações de estudantes que lutavam contra a falta de merendas nas escolas. O ministro dos Transportes declarou medidas de privatização de infraestrutura; o ministro da Saúde, Ricardo Barros, indicou a ampliação das parcerias público-privadas (PPPs), cortes de gastos e receita para o Samu e Farmácia Popular. O ministro da Fazenda, Henrique Meirelles, apresenta como principais medidas mais uma contrarreforma trabalhista e da Previdência e trabalhista; busca ainda garantir o ajuste fiscal desejado pelos empresários e banqueiros a serviço da estratégia imperialista internacional, com cortes nas despesas públicas da saúde, habitação, educação, direitos sociais e trabalhistas, O ministro do Trabalho Ronaldo Nogueira propõe desvincular pensões e aposentadorias dos reajustes de salário mínimo no Brasil; retirada dos direitos garantidos pela CLT, fim da estabilidade para os trabalhadores em serviço público; acabar com a política de aumento real de salário em um verdadeiro 
estado de exceção ao aniquilar a Constituição. A Medida Provisória n. 727 do governo Temer cria o Programa de Parcerias de Investimento (PPI) baseado nas leis de desestatização de FHC, n. 971 e n. 9.941. O ministro da Reforma Agrária e do Desenvolvimento Social Osmar Terra, do PMDB, declarou que se houver agitação, o MST perderá recursos, em uma ameaça punitiva.

A situação dos trabalhadores terceirizados no Brasil é dramática. Em 1995, no governo de FHC, havia 1,8 milhão de trabalhadores terceirizados; em 2005, no segundo ano do primeiro governo Lula, havia 4,1 milhões, o que significou $127 \%$ de aumento; e em 2013, no primeiro governo de Dilma Rousseff, os dados são de 12,7 milhões, o que corresponde a um aumento de $217 \%$. Os dados no governo ilegítimo de Temer já atinge 13 milhões de trabalhadores terceirizados. Essa lógica é parte das medidas internacionais do grande capital sobre o trabalho, que os empresários seguem à risca para continuar acumulando capital.

Em 2016, dos 45 milhões de trabalhadores assalariados existentes, 13 milhões são terceirizados, e a proposta é a de transformar mais 32 milhões contratados também em terceirizados. De acordo com os índices do Departamento Intersindical de Estatística e Estudos Socioeconômicos (Dieese), os trabalhadores terceirizados recebem $24,7 \%$ a menos que os contratados; trabalham em média 47 horas semanais, $7,5 \%$ a mais do que os contratados; permanecem menos tempo no emprego, 2,7 anos contra 5,8 dos contratados; a média de rotatividade dos terceirizados é de $64,4 \%$ contra $33,0 \%$ dos contratados, o que significa o dobro de rotatividade; $90 \%$ dos trabalhos análogos à escravidão os envolvem; a maioria dos trabalhadores terceirizados é composta por jovens, negros, mulheres, lésbicas, gays, bissexuais, travestis, transgêneros, transexuais (LGBTT), e por aposentados que tentam complementar suas pequenas aposentadorias. Entre os trabalhadores que exercem a mesma função, as mulheres percebem menores salários que os homens, e as negras são as últimas na escala salarial. De dez trabalhadores que sofrem acidentes de trabalho, oito são terceirizados. Em 2014, 2.794 pessoas morreram em decorrência de acidente de trabalho; 14.837 se tornaram incapacitadas para o trabalho, e ocorreram 737.378 acidentes de trabalho, $90 \%$ dos quais envolviam terceirizados. O projeto de lei da terceirização ainda prevê a perda ou a redução de direitos, como a licença-maternidade, a licença-paternidade e o abono assiduidade. No que se refere aos jovens, em janei- 
ro de $2016,50 \%$ eram terceirizados, $19,8 \%$ se encontravam desocupados, e $20 \%$, desempregados, o que expressa um quadro avassalador. Nossa posição de luta contra todas as formas de terceirização deve ser prioritária, bem como a contratação de todos os terceirizados sem concurso, por já terem uma prática acumulada na função exercida. Portanto, trata-se de saldar uma dívida histórica com esses trabalhadores terceirizados e duramente precarizados.

Os ajustes fiscais de 2015 e 2016 do governo Dilma recaíram sobre cortes nos programas sociais de saúde, educação, habitação - Minha Casa Minha Vida -, no reajuste de servidores federais, de subvenção agrícola, suspensão de concursos públicos, ampliação da idade para aposentadoria, eliminação do abono de permanência para garantir a meta do superávit primário de $0,7 \%$ do PIB em 2016, ou seja, com ataques à classe trabalhadora e sequer sobre taxação das grandes empresas e juros bancários. Acrescenta-se o Programa de Proteção ao Emprego (PPE), que trata na realidade de um programa de proteção ao empresário que prevê a diminuição de horas trabalhadas com redução de salários, e os Decretos n. 664 e 665, que reduziram a pensão por morte a $50 \%$ de seu valor. Deve-se considerar também o seguro-desemprego, que, regulamentado para depois de seis meses, foi ampliado para um ano, o que, com o aumento de rotatividade de mão de obra, inviabiliza esse seguro; a retirada de programas sociais como o Bolsa Família por ocasião do seguro defeso, atribuído aos pescadores profissionais que exercem suas funções de forma artesanal, e que paralisam suas atividades no período determinado para a preservação da espécie.

Esse conjunto de regulamentações que recaem sobre a classe trabalhadora requer uma ação unitária de lutas, com greves gerais para a retomada desses direitos que estão sendo destruídos, e a esquerda deve ter um papel fundamental nesse processo com autonomia e independência de classe.

O PL n. 257/2016, que se encontra em tramitação no Congresso Nacional, já aprovado na Câmara dos Deputados, de iniciativa do Executivo do governo Dilma, acelerado no governo Temer, é a condição para a renegociação da dívida dos estados com a federação. O PL parte do ajuste fiscal no final de 2014 e atinge diretamente o serviço público nos programas sociais e trabalhadores, com medidas como: a suspensão de concursos públicos com a contratação somente de trabalhadores terceirizados; o corte por dois anos de direitos adquiri- 
dos; o congelamento de salários em período a ser definido; o não pagamento de progressões e outras vantagens, como gratificações; a destruição da Previdência Social e revisão dos regimes jurídicos dos servidores; o programa de demissão voluntária para os trabalhadores em serviço público; o fim da licença-prêmio; o aumento da contribuição previdenciária de $11 \%$ para $14 \%$; a instalação do regime de urgência para aprovação desse projeto em cinco meses. Em nome da "responsabilidade fiscal", a serviço da hegemonia do capital especulativo-parasitário, tem capturado o fundo público, que deveria se voltar para assistência social, previdência, educação, saúde, serviços e trabalho de qualidade, com remuneração e recursos orçamentários do fundo público.

\section{As mobilizações sociais e greves em curso no país - 2013 aos primeiros meses de 2016}

Em junho de 2013 ocorreram grandes mobilizações de massa, impulsionadas pelos jovens, que tomaram as ruas do país na luta pela redução da tarifa dos transportes - a partir do Movimento Passe Livre (MPL), e na sequência se ampliaram com setores populares vindos das periferias dos centros urbanos que se expressaram contra o alto custo de vida e a ausência e/ou precarização de serviços de educação, saúde e habitação. A polícia agiu com a truculência da ditadura militar, nos governos do PSDB e do PMDB, nos estados, e o PT fez coro ao autoritarismo. Após a brutal repressão no dia 13/6/2013, em São Paulo, os governos recuaram nos ataques e tentaram de forma reacionária impor a ideia de nacionalismo, patriotismo e apartidarismo. Entre 13 e 20/6/13, cerca de doze prefeitos de capitais e cidades do interior reduziram o preço do transporte, e mais de cem cidades em todo o país fizeram mobilizações de rua e bloqueios de estradas, chegando a quase 1 milhão de pessoas de Norte a Sul do país nas ruas, em sucessivos dias de mobilização de massas. A Rede Globo e grande parte da imprensa foram ao ar para enfatizar que as mobilizações deveriam ser apartidárias para minar, neutralizar a possibilidade de politização das massas para a luta anticapitalista. O movimento de massas foi heterogêneo, difuso, mas havia um sentimento generalizado de descontentamento com a precarização da vida e um descrédito significativo com os partidos da oficialidade, e muitas vezes nas 
mobilizações chegaram a negar as bandeiras vermelhas dos partidos e organizações de esquerda por identificá-los com o PT. Os gastos de R \$ 28 bilhões com a Copa, em detrimento dos gastos com educação, saúde, transporte, habitação e reforma agrária, foram denunciados e geraram grandes mobilizações em 2014, sob forte repressão e com criminalização aos movimentos sociais.

Desde 2012, vivencia-se no país um número significativo de greves; entre 2014 e 2016, elas ocorreram contra as demissões, a precarização do trabalho, as contrarreformas, a não negociação de perdas salariais e superaram os movimentos grevistas realizados nos anos 1990. As greves do último período já são consideradas as mais expressivas, qualitativa e quantitativamente, em setores da produção e reprodução social em serviços de educação, saúde, limpeza, a saber: metalúrgicos, garis, trabalhadores da construção civil, professores das universidades federais, trabalhadores das universidades e serviços públicos municipais, estaduais e federais, petroleiros, bancários, metroviários, trabalhadores terceirizados; greves que ocorreram e continuam ocorrendo em muitos estados da federação. Muitas categorias passaram por cima das direções pelegas (como as dos sindicatos de terceirizados) e da CUT (petroleiros) e se organizaram para greves econômicas e políticas. As greves, as ocupações de terras, as mobilizações por moradias e as ocupações de fábricas falidas, em 2016, pelos operários na tentativa de auto-organização dos trabalhadores são expressão desse caráter explosivo e ofensivo das lutas de classe no país.

Os indígenas e quilombolas deram continuidade às reivindicações pela demarcação de áreas sob forte repressão, advinda de fazendeiros, do agronegócio, das mineradoras. Movimentos contra a privatização da saúde, pelos direitos LGBTT, contra o racismo e genocídio da população negra e pobre dos morros e periferias da cidade, movimento e luta das mulheres trabalhadoras contra a opressão e a discriminação e na luta por direitos também se expressaram em mobilizações generalizadas. Em 2015 e 2016 expandiu-se um grande movimento de estudantes secundaristas, com ocupação das escolas em defesa da educação. No caso do estado de São Paulo, o movimento foi contra a reorganização imposta pelo governo Alckmin, que precariza ainda mais o ensino, sendo que em 2016 foi na luta pela merenda escolar. Essas ocupações em defesa do ensino de qualidade ocorreram e continuaram ocorrendo em vários estados, como São Paulo, Rio de Janeiro, Goiás, Paraná, Pará, Ceará, Minas Gerais, Rio Gran- 
de do Sul, com ocupações e auto-organização de estudantes, o que demonstra a capacidade de organização e luta classista dos trabalhadores e da juventude. A conjuntura exige dos marxistas revolucionários, lutadores dos movimentos sociais populares, das centrais sindicais a unidade de ação nas lutas e de construção de um bloco de esquerda permanente para enfrentar a destruição das conquistas e avançar na luta anticapitalista, socialista.

\section{Desafios para o Serviço Social e para os profissionais}

O Serviço Social brasileiro teve no III Congresso Brasileiro de Assistentes Sociais, em 1979, sua ruptura pública e coletiva com o conservadorismo. Esse movimento se estabeleceu no processo de efervescência da luta de classes no país, em que os setores organizados e combativos da categoria retomam suas entidades sindicais desativadas durante a ditadura militar e se vinculam organicamente ao sindicalismo classista de lutas expresso na Articulação dos Movimentos Populares e Sindicais (Anampos) e posteriormente na CUT, com sua fundação em 1983. Os assistentes sociais se reconhecem como trabalhadores, em sua condição de assalariamento, inscritos na divisão sociotécnica do trabalho. Nos anos 1980, definem a direção social da profissão voltada e articulada aos interesses imediatos e históricos da classe trabalhadora. Os setores de vanguarda que atuam nos sindicatos da categoria estabelecem um duplo movimento: na área sindical, passam a construir, juntamente com outros trabalhadores, o Sindicato dos Servidores Públicos, e a partir de 1988 avançam gradativamente para a construção dos sindicatos por ramos de atividade (saúde, previdência) ou contratação (trabalhadores em serviço público municipal) de modo a extinguir a Associação Nacional dos Assistentes Sociais (Anas) e os sindicatos de categoria por deliberação unânime no Congresso Sindical de 1989. De outro lado, estabeleceram uma estratégia para disputar os Cress e CFESS (à época Cras e CFAS) que estavam sob a direção de profissionais alinhados à tecnocracia e ao conservadorismo na profissão. Esse movimento, iniciado nos anos 1980, tem até o final da década uma direção renovada na perspectiva do Projeto Ético-Político do Serviço Social brasileiro. Ocorre também no plano da formação profissional um movimento progressista que irá 
definir o projeto de profissão, a partir do legado marxiano e da tradição marxista que tem, na teoria social de Marx, a perspectiva da totalidade em que o trabalho é reafirmado como categoria fundante do ser social, acrescida da articulação política com os estudantes por meio de sua representação, a Enesso. Nos anos 1990 definimos o novo Código de Ética, a nova lei de regulamentação da profissão e as diretrizes curriculares, que se configuram nossos parâmetros do Projeto Ético-Político Profissional, o qual se encontra articulado a um projeto societário emancipatório. Esse movimento da categoria profissional desde a luta contra a ditadura, pela redemocratização do país, se espraia a partir de 1989, na luta contra o neoliberalismo, e reafirma o projeto profissional articulado com o projeto societário emancipatório. Nesse sentido, estivemos e continuamos cerrando fileiras com o sindicalismo classista e movimentos sociais em defesa dos direitos sociais e trabalhistas, contra toda forma de exploração, preconceito, opressão e discriminação, assim como estivemos e estamos presentes contra as medidas de desregulamentação das relações de trabalho, contra os ajustes fiscais de todos os governos neoliberais, contra as contrarreformas sindical, trabalhista, da Previdência Social, do ensino superior, em defesa dos direitos sociais e trabalhistas conquistados, contra a lesbofobia, pelo direito ao aborto, em defesa da reforma agrária e urbana, pela demarcação das terras indígenas e quilombolas e contra o golpe institucional parlamentar de direita em curso no país. $\mathrm{O}$ artigo ora apresentado pretende ser uma contribuição aos profissionais, aos trabalhadores em geral, aos estudantes, à juventude, à(aos) lutadores(as) para os desafios presentes na realidade sócio-histórica, conjuntural e estrutural do capitalismo contemporâneo frente à ampliação da exploração, da desigualdade, da opressão e da discriminação de classe, gênero, raça, etnia, orientação sexual e geracional. Os congressos da categoria (CBAS), os encontros no âmbito do exercício profissional (CFESS-CRESS), as oficinas da Abepss e Enpess, os encontros da Enesso têm se colocado no sentido de reafirmar o Projeto Ético-Político profissional do Serviço Social brasileiro e têm se posicionado ativamente e de forma autônoma e independente como a construímos e a consolidamos pela práxis ética, política, teórica, profissional no sentido. As resoluções de nossas entidades ao longo desses 37 anos vão na direção da luta por igualdade e liberdade, e somamos fileiras com os trabalhadores na luta anticapitalista, emancipatória. 


\section{III-CONCLUSÃO}

A conjuntura do país encontra-se em uma crise política profunda diretamente vinculada à crise econômica nacional e do capital no plano internacional. As medidas de ataques e de destruição de direitos e conquistas são avassaladoras, podendo levar a um retrocesso brutal em relação aos direitos trabalhistas, retornando a patamares anteriores à CLT dos anos 1930, além de medidas moralizantes em curso pautadas por orientações fundamentalistas presentes no Congresso Nacional. Há uma falácia dos governos de conciliação de classes em toda a América Latina, que se autodesignaram "democrático-populares", mas que com maior ou menor adesão cumpriram a programática neoliberal, com contrarreformas, privatizações, decretos, ajustes fiscais com cortes estrondosos nas áreas sociais, desconsiderando as grandes reivindicações e conquistas da classe trabalhadora que os elegeu, como ocorreu nos governos Lula e mais fortemente no segundo governo Dilma.

De outro lado há o avanço destruidor da direita em todo o continente, e, no Brasil, agravado pelo golpe institucional. É preciso lutar contra: os ajustes fiscais e projetos que tramitam no Congresso Nacional; o golpe e o governo golpista ilegítimo de Temer, que aprofunda a crise e os ataques sobre os trabalhadores em defesa das reivindicações e conquistas dos trabalhadores.

A construção de uma frente de esquerda classista, de oposição e práxis anticapitalista, anti-imperialista, socialista, pautada nas lutas da classe operária, dos trabalhadores rurais e urbanos, da juventude, das mulheres, dos indígenas, dos sem-terra, dos sem-teto, dos negros e negras, da população em situação de rua, do seguimento LGBTT e de todos(as) trabalhadores(as) que sofrem exploração, dominação e opressão social de classe, gênero, raça, etnia e orientação sexual, é uma necessidade imediata para a unificação das lutas e dos lutadores. Nessa frente devem estar articulados os partidos de esquerda, como o Partido Comunista Brasileiro (PCB), o Partido Socialista dos Trabalhadores Unificados (PSTU) Partido Socialismo e Liberdade (Psol), o Partido Comunista Operário (PCO), as organizações de esquerda, como a Nova Organização Socialista (NOS), o Movimento Revolucionário dos Trabalhadores (MRT), o Partido Operário Revolucionário (POR), o Movimento por uma Alternativa Indepen- 
dente e Socialista (Mais); os lutadores classistas anarquistas, a esquerda marxista, centrais sindicais como a CSP - Conlutas e Intersindical e entidades sindicais, de categorias profissionais e movimentos sociais, populares e específicos (LGBTT), negros, mulheres, indígenas, moradia, sem-teto, sem-terra, populações originárias, habitação, transporte, educação, juventude, secundaristas, trabalhadores operários, da esfera da produção e reprodução social, entre outras organizações que cerram fileiras nas lutas e todos aqueles que são contrários ao governo golpista ilegítimo para derrotá-lo nas ruas, nos locais de trabalho, nas ocupações, nas greves, nas lutas pelos direitos e conquistas da classe trabalhadora, no campo e na cidade... . "Socialismo ou barbárie" é o legado que nos deixou Rosa Luxemburgo ao se deparar com o futuro da humanidade face às mazelas destrutivas do capital. Essa referência é atual e premente na luta por um projeto societário comum a todos, como nos afirmou Marx, comunista, libertário, igualitário, de emancipação humana.

$\mathrm{Na}$ direção de continuidade do projeto profissional hegemônico, que consolidamos ao longo dos últimos 37 anos, os elementos aqui tratados são referência de práxis para nossa organização e luta na formação e no exercício profissional articulados à perspectiva de uma sociabilidade emancipada.

Recebido em 1/9/2016 - Aprovado em 16/2/2017 